\title{
Hubungan Self Efficasy dan Motivasi dengan Pemahaman Konsep IPA Terpadu Siswa Kelas VIII SMP Pertiwi 2 Padang
}

\author{
Reni Nastuti ${ }^{1}$ Lelfita $^{2}$, Elbasthoh ${ }^{3}$ \\ Program Studi Pendidikan Fisika ${ }^{1,2,3}$ \\ Sekolah Tinggi Keguruan dan Ilmu Pendidikan Yayasan Dharma Bakti \\ Jln Pulau Jantung Indah No 91 Lubuk Alung.Telp 0751-96079 \\ Email: reni.nastuti@gmail.com
}

\begin{abstract}
The research aims to describe 1.The relationship of self-efficacy and the students' understanding of the concept of Pertiwi 2 Junior High School Padang. 2. The relationship of motivation and the understanding of the concept of Pertiwi 2 Junior High School students. Factors that can influence a student's understanding of concept are not only depend on the media, model, strategy and learning environment but depend on the students themselves which are self efficacy and motivation. The research is begun at the beginning of the even semester of 2017/2018 academic year. The population in this study was eight (VIII) grade students of Pertiwi 2 Junior High School Padang. The variables consisted of self efficacy (X1), motivation (X2) and understanding of concept (Y). The sample used random sampling which totaled 52 samples. The type of research is descriptive research. The instrument used in this study is questionnaire. The essay as a test is given at the end of Science study to find out the students' level of understanding concepts. Based on the data analysis self efficacy 0.184 in the lowest relationship level. According to the significance test, was used t test, in real level $\propto=0,05$ with degree of freedom $(d k=44)$ was obtained $t_{\text {table }} 1,68$. Based on the criteria of the test, $t_{\text {table }}=1.68$ and $t$ count $=1.243$. Means $\mathrm{Hi}$ was rejected and $H_{0}$ was accepted. The motivation relationship level is 0.089 in the lowest level. Based on the significance test, was used t test, in real level $=0,05$ with degree of freedom $(d k=44)$ was obtained $t_{\text {table }} 1,68$. The test's criteria result is $t_{\text {table }}$ $=1,68$ dan $t$ count $=0.593$. Means $H i$ is rejected and $H_{0}$ was accepted. So, it can be concluded as there is no significant relationship of self efficacy and motivation with the understanding of concepts of integrated science in VIII class of Pertiwi 2 Junior High School Padang.
\end{abstract}

Keywords: self efficacy, motivation and understanding concept.

\section{PENDAHULUAN}

IPA Terpadu merupakan salah satu cabang sain yang berperanan penting dalam meningkatkan Kemajuan Ilmu Pengetahuan alam dan Teknologi. Perkembangan ilmu pengetahuan dan teknologi yang pesat menyebabkan tuntutan masyarakat dalam berbagai bidang kehidupan berubah dan berkembang secara cepat. Ilmu pengetahuan dan teknologi dapat membawa perubahan nilai-nilai pada masyarakat sehingga masyarakat memerlukan kesiapan pengetahuan dan keterampilan baru yang memadai untuk menghadapi perubahan yang terjadi termasuk dalam bidang pendidikan. Semakin maju tingkat pendidikan suatu negara maka semakin tinggi kualitas sumber daya manusianya, sehingga setiap negara berupaya untuk memajukan pendidikannya.

Perubahan perubahan dan upaya dalam meningkatkan mutu pendidikan di Indonesia telah lama dilakukan. Berbagai perubahan program pendidikan juga telah dilaksanakan, antara lain penyempurnaan kurikulum, pengadaan buku ajar, sarana laboratorium, peningkatan mutu guru melalui kegiatan seminar dan pelatihan terus di tingkatkan. Semuanya itu belum menampatkan hasil yang maksimal. Dalam proses belajar mengajar self efficacy dan motivasi merupakan salah satu faktor yang mempengaruh terhadap hasil belajar. motivasi adalah sebagai pendorong usaha dan pencapaian prestasi" (Sardiman, 2001 : 83). Jelaslah bahwa fungsi motivasi itu memberikan suatu nilai atau itensitas tersendiri dari seorang siswa dalam meningkatkan motivasi belajar dan prestasi belajarnya. Siswa yang memiliki self efficacy dan motivasi tinggi diduga akan memperoleh hasil belajar yang baik. Pentingnya motivasi belajar siswa terbentuk antara lain agar terjadi perubahan belajar ke arah yang lebih positif. Pandangan ini sesuai dengan Pendapat Hawley (Prayitno, 1989:3) : "Siswa yang termotivasi 
dengan baik dalam belajar melakukan kegiatan lebih banyak dan lebih cepat, dibandingkan dengan siswa yang kurang termotivasi dalam belajar. Prestasi yang diraih akan lebih baik apabila mempunyai motivasi yang tinggi."

Pemahaman konsep siswa terhadap suatu konsep merupakan tujuan dalam Pendidikan IPA, Pelajaran IPA Terpadu merupakan salah satu pelajaran yang memiliki Karakteristik tersendiri dan memerlukan keterampilan khusus dalam memecahkan masalah-masalah yang berupa teori, konsep, hukum dan fakta, banyak factor yang membuat siswa dapat memahami konsep diantaranya self efficacy. Santrock (2009:462) mengatakan bahwa self efficacy adalah keyakinan bahwa saya bisa. Keyakinan yang dimiliki oleh setiap siswa sangat berpengaruh terhadap keberhasilan dalam belajar. Bandura (1994) dalam (feldman 2006:51)mengungkapkan bahwa self-efficacy didefinisikan sebagai perasaan mampu menguasai tantangan dan mencapai tujuan. Dimana self efficacy sangat berpengaruh didalam proses pembelajaran, sepintar apa pun seseorang jika ia tidak memiliki perasaan mampu untuk menguasai tantangan ia tidak akan berhasil di dalam pembelajaran. Selain self efficacy motivasi dalam belajar juga sangat di perlukan karena Motivasi dalam belajar dapat menumbuhkan hasrat dan keinginan untuk belajar. Siswa yang memiliki motivasi kuat akan mempunyai banyak energi untuk melakukan kegiatan belajar. Seorang siswa yang memiliki inteligensia cukup tinggi bisa menjadi gagal jika motivasi dalam dirinya kurang (Sardiman, 2008:75). Motivasi merupakan unsur yang mempengaruhi pemahaman konsep IPA Terpadu siswa. Menurut Qonita Alya (2011:472) "motivasi adalah dorongan yang timbul pada diri seseorang secara sadar atau tidak sadar untuk melakukan suatu tindakan dengan tujuan tertentu". Sedangkan menurut Purwanto (2007:71) motivasi adalah "dorongan atau suatu usaha yang didasari untuk mempengaruhi tingkah laku seseorang agar ia tergerak hatinya untuk bertindak melakukan sesuatu sehingga mencapai hasil atau tujuan tertentu". Jadi dapat penulis simpulkan bahwa motivasi adalah dorongan dalam diri seseorang dalam mencapai suatu tujuan yang hendak dicapai

Namun pada kenyataannya, pentingnya peran self efficacy dan motivasi tidak dirasakan oleh beberapa siswa. Terkadang siswa menganggap bahwa jika mereka pandai pasti mereka selalu mendapatkan nilai yang bagus, begitu sebaliknya. Meskipun begitu, siswa yang pandai belum tentu selalu memperoleh hasil belajar yang memuaskan, seperti yang telah dikemukakan di atas bahwa belajar tidak hanya dipengaruhi oleh tingkat kepandaian siswa, namun belajar dipengaruhi oleh.banyak faktor. Jika salah satu faktor tersebut menghambat siswa, maka akan berpengaruh pada hasil belajarnya. Kesulitan untuk memahami konsep-konsep kimia berhubungan dengan pemahaman yang dimiliki siswa. Pemahaman merupakan bagian dari kognitif. Selama ini yang di sadari oleh masyarakat adalah siswa yang dapat memahami konsep adalah siswa yang memiliki IQ yang tinggi, tanpa menyadari bahwa konsep dapat di pahami oleh siswa, karena oleh banyak factor. Berdasarkan uraian di atas, maka rumusan masalah dalam penelitian ini adalah apakah terdapat hubungan yang signifikan self efficacy dan motivasi terhadap hasil belajar siswa sedang kan tujuan dari penelitian ini adalah untuk mendeskripsikan hubungan self efficacy dan motivasi terhadap pemahaman konsep IPA siswa SMP Pertiwi 2 Padang.

\section{METODE PENELITIAN}

Jenis penelitian ini adalah penilitian kuantitatif mengunakan korelasi produt moment Populasi dalam penelitian ini adalah siswa kelas VIII SMP Pertiwi 2 Padang. Teknik pengambilan sampel dalam penelitian ini adalah Purposiv Sampling yang berjumlah sebanyak 52 orang siswa. Instrumen yang digunakan dalam pengumpulan data penelitian yaitu angket self efficacy dan motiavasi yang sudah di validasi, Menurut Sugiyono (2014:121) "instrumen yang valid berarti alat ukur yang digunakan untuk mendapatkan data itu valid. Menurut Arikunto (1995:63) dalam buku Riduwan bahwa, "Validitas adalah suatu ukuran yang menunjukkan tingkat keandalan atau kesahihan suat alat ukur dimana pada angket tersebut terdapat 60 pernyataan yang terdiri dari 30 pernyataan untuk self efficacy dan 30 pernyataan untuk motivasi, yang terdiri dari pernyataan positive dan pernyataan negative. Pernyataan disusun mengunakan empat alternative jawaban, Skala pengukuran self efficacy ini memiliki empat pilihan jawaban atas pernyataan yang ada, yaitu: Sangat Setuju (SS), Setuju (S), Tidak 
Setuju(TS), dan Sangat Tidak Setuju (STS) sedangkan untuk pemahaman konsep dengan mengunakan instrument berupa soal esay yang diberikan pada akhir jam pelajaran IPA Terpadu. Variabel dalam penelitian ini terdiri dari variable bebas ( self efficacy dan motivasi $=\mathrm{X} 1$ dan $\mathrm{X} 2$ ) dan variabel terikat (pemahaman konsep $=\mathrm{Y}$ ). Teknik analisis data yang digunakan adalah analisis korelasi dengan mengunakan uji korelasi product moment. Uji prasyarat analisis menunjukkan bahwa data berdistribusi normal dan dan homogen

\section{HASIL DAN PEMBAHASAN}

Sugiyono (2014:147), "analisis data merupakan kegiatan setelah data dari seluruh responden atau sumber data lain terkumpul".Data yang diperoleh dideskripsikan sesuai dengan tujuan penelitian yaitu untuk mendeskripsikan hubungan Self efficacy dan motivasi dengan hasil belajar. Hasil dari angket Self Efficasy yang diperoleh dari siswa setelah ditabulasi didapatkan nilai tertinggi 106 dan terendah 73, Mean 89,5 dan standar deviasi 5,5. Sedangkan dari angket motivasi diperoleh nilai tertinggi 111 dan terendah 71, Mean 91 dan standar deviasi dengan hasil 6,7.Kategori Self Efficasy dan motivasi dapat dilihat pada tabel di bawah ini.

Tabel 1. Identifikasi Kategori Self Efficasy

\begin{tabular}{ccccc}
\hline No & Formula & Hitungan & Rentang Skor & Kategori \\
\hline 1 & (x) $>$ Mi $+1 \mathrm{SD}$ & $\mathrm{X}>89,5$ & $91-106$ & Tinggi \\
2 & $\mathrm{Mi}-1 \mathrm{SD} \leq \chi \leq \mathrm{Mi}+1 \mathrm{SD}$ & $84 \leq \chi \leq 95$ & $85-90$ & Sedang \\
3 & $(\mathrm{x})<\mathrm{Mi}-1 \mathrm{SD}$ & $\mathrm{X}<84$ & $73-84$ & Rendah \\
\hline
\end{tabular}

(sumber: hasil analisis penelitian)

Berdasarkan tabel di atas, maka kategori tingkat Self Efficasy dengan rentang skor 91 106 memiliki kategori tinggi, rentang skor 85
- 90 memiliki kategori sedang dan rentang skor $73-84$ memiliki kategori rendah.

Tabel 2. Identifikasi Kategori motivasi

\begin{tabular}{ccccc}
\hline No & Formula & Hitungan & Rentang Skor & Kategori \\
\hline 1 & $(\mathrm{x})>\mathrm{Mi}+1 \mathrm{SD}$ & $\mathrm{X}>97.1$ & $99-111$ & Tinggi \\
2 & $\mathrm{Mi}-1 \mathrm{SD} \leq \chi \leq \mathrm{Mi}+1 \mathrm{SD}$ & $84.3 \leq \chi \leq 97.7$ & $86-98$ & Sedang \\
3 & $(\mathrm{x})<\mathrm{Mi}-1 \mathrm{SD}$ & $\mathrm{X}<84.3$ & $71-85$ & Rendah \\
\hline
\end{tabular}

(sumber: hasil analisis penelitian)

Berdasarkan tabel di atas, maka kategori tingkat motivasi dengan rentang skor $99-111$ memiliki kategori tinggi, rentang skor 86 - 98 memiliki kategori sedang dan rentang skor 71
- 85 memiliki kategori rendah. Sedangkan kategori Self Efficasy dan motivasi dapat dilihat pada tabel 3 dan 4 di bawah ini.

Tabel 3.Kategori Tingkat Self Efficasy

\begin{tabular}{cccc}
\hline No & Rentang Skor & Frekuensi & Kategori \\
\hline 1 & $91-106$ & 16 siswa & Tinggi \\
2 & $85-90$ & 12 siswa & Sedang \\
3 & $73-84$ & 18 siswa & Rendah \\
& Jumlah & 46 siswa & \\
\hline
\end{tabular}

Pada Tabel 3 terlihat bahwa tingkatan Self Efficasy dengan kategori tinggi sebanyak 16 orang siswa, kategori sedang sebanyak 12 siswa dan kategori rendah sebanyak 18 orang siswa sedangkan kategori tingkat motivasi dapat dilihat pada table 4 di bawah ini

Tabel 4. Kategori Tingkat motivasi

\begin{tabular}{cccc}
\hline No & Rentang Skor & Frekuensi & Kategori \\
\hline 1 & $99-111$ & 13 siswa & Tinggi \\
2 & $86-98$ & 24 siswa & Sedang \\
3 & $71-85$ & 9 siswa & Rendah \\
& Jumlah & 46 siswa & \\
\hline
\end{tabular}


Pada Tabel .4 terlihat bahwa tingkatan motivasi dengan kategori tinggi sebanyak 13 orang siswa, kategori sedang sebanyak 24 siswa dan kategori rendah sebanyak 9 orang siswa.
Selanjutnya Kategori tingkat Self Efficasy dengan hasil belajar IPA terpadu siswa dapat dilihat pada Tabel 5 dibawah ini.

Tabel 5. Kategori Tingkat Self Efficasy dengan Hasil Belajar

\begin{tabular}{ccccc}
\hline \multirow{2}{*}{ No } & Tingkat Self Efficasy & Frekuensi & \multicolumn{2}{c}{ Hasil Belajar } \\
& & 16 siswa & 8 siswa & 8 siswa \\
1 & Tinggi & 12 siswa & 6 siswa & 6 siswa \\
3 & Sedang & 18 siswa & 4 siswa & 14 siswa \\
& Rendah & 46 siswa & $\mathbf{1 8}$ siswa & $\mathbf{2 8}$ siswa \\
\hline
\end{tabular}

Pada table di atas dapat dilihat bahwa tingkat self efficacy siswa yang tinggi memiliki nilai $\geq \mathbf{7 5}$ sebanyak 8 orang, tingkat self efficacy siswa yang sedang memiliki nilai $\geq 75$ sebanyak 6 orang siswa dan siswa yang tingkat self efficacy rendah memiliki nilai $\geq \mathbf{7 5}$ sebanyak 4 orang. Sedangkan kategori tingkat motivasi dengan hasil belajar dapat dilihat pada table 6 di bawah ini

Tabel 6.Kategori Tingkat motivasi dengan Hasil Belajar

\begin{tabular}{ccccc}
\hline \multirow{2}{*}{ No } & Tingkat motivasi & Frekuensi & $\mathbf{2}$ Hasil Belajar \\
& & & $\mathbf{7 5}$ & $<\mathbf{7 5}$ \\
2 & Tinggi & 15 siswa & 9 siswa & 6 siswa \\
3 & Sedang & 22 siswa & 7 siswa & 15 siswa \\
& Rendah & 9 siswa & 2 siswa & 7 siswa \\
& Jumlah & $\mathbf{4 6}$ siswa & $\mathbf{1 8}$ siswa & $\mathbf{2 8}$ siswa \\
\hline
\end{tabular}

Pada table di atas dapat dilihat bahwa tingkat motivasi siswa tinggi memiliki nilai $\geq$ 75 sebanyak 9 orang, tingkat motivasi siswa yang sedang memiliki nilai $\geq \mathbf{7 5}$ sebanyak 7 orang siswa dan siswa yang tingkat motivasi rendah memiliki nilai $\geq \mathbf{7 5}$ sebanyak 2 orang.
Uji normalitas dilakukan pada masingmasing variabel, yaitu Self Efficasy dengan hasil belajar. Dan motivasi dengan hasil belajar. uji normalitas Self Efficasy yang telah penulis lakukan, maka didapat harga $\mathrm{L}_{\text {hitung }}$ dan $\mathrm{L}_{\text {tabel }}$ pada taraf nyata 0,05 seperti yang tertera pada Tabel dibawah ini.

Tabel 7. Uji Normalitas Self Efficasy dengan Hasil Belajar

\begin{tabular}{ccccc}
\hline Variabel & $\mathbf{N}$ & $\mathbf{L}_{\text {hitung }}$ & L $_{\text {tabel }}$ & Keterangan \\
\hline $\mathrm{X}$ & 46 & $\mathbf{0 . 0 9 1}$ & 0.131 & Normal \\
$\mathrm{Y}$ & 46 & $\mathbf{0 . 1 3 0 9 0 8 6 9 6}$ & 0.131 & Normal \\
\hline
\end{tabular}

Berdasarkan uji normalitas Motivasi dan hasil belajar, maka didapat harga $\mathrm{L}_{\text {hitung }}$ dan
$\mathrm{L}_{\text {tabel }}$ pada taraf nyata 0,05 seperti pada Tabel 8 dibawah ini.

Tabel 8.Uji Normalitas Motivasi Dan Hasil Belajar

\begin{tabular}{ccccc}
\hline Variabel & $\mathbf{N}$ & $\mathbf{L h i t u n g}_{\text {Ltabel }}$ & Keterangan \\
\hline $\mathrm{X}$ & 46 & $\mathbf{0 . 0 6 8 2 8 2 6 0 9}$ & 0.131 & Normal \\
$\mathrm{Y}$ & 46 & $\mathbf{0 . 1 3 0 9 0 8 6 9 6}$ & 0.131 & Normal \\
\hline
\end{tabular}

Dari Tabel 7 dan 8 dapat dilihat pada kedua kelas didapatkan $\mathrm{L}_{\text {hitung }}<\mathrm{L}_{\text {tabel}}$, ini berarti bahwa data yang didapatkan dari kedua sampel penelitian ini terdistribusi normal, kemudian dilanjutkan dengan Uji homogenitas untuk melihat apakah kedua variabel sampel memiliki variansi yang homogen atau tidak, rumus yang dipakai adalah uji F. Hasil homogenitas kedua variabel sampel dapat dilihat nilai $\mathrm{F}_{\mathrm{t}}<\mathrm{F}_{\mathrm{h}}$, ini berarti data pada kedua variabel sampel berasal dari populasi yang homogen.uji homogenitas dapat dilihat pada table di bawah ini. 
Tabel 9. Uji Homogenitas

\begin{tabular}{cccccc}
\hline Variabel & $\mathbf{S}^{2}$ & $\mathbf{N}$ & $\mathbf{L}_{\text {tabel }}$ & Lhitung & Keterangan \\
\hline $\mathrm{X}$ & 87.30 & 46 & 1.62 & 1.43 & homogen \\
$\mathrm{Y}$ & 124.74 & 46 & & & \\
\hline
\end{tabular}

Dari Tabel 9.dapat dilihat nilai $\mathrm{F}_{\mathrm{t}}>\mathrm{F}_{\mathrm{h}}$, ini berarti data pada kedua variabel sampel berasal dari populasi yang homogen.

\section{Uji Hipotesis}

Berdasarkan uji normalitas dan homogenitas Self efficasy siswa dengan hasil belajar fisika diperoleh data berdistribusi normal, maka syarat penggunaan korelasi product moment sudah terpenuhi. Untuk mengetahui secara statistik hubungan antara Self Efficasy dengan hasil belajar IPA Terpadu digunakan rumus korelasi product moment. Hasil dari pengujian hipotesis dapat dilihat pada tabel 10 dibawah ini.

Tabel 10. Uji Hipotesis

\begin{tabular}{cccc}
\hline Kelas & $\mathbf{r}_{\mathbf{x y}}$ & $\mathbf{t}_{\mathbf{h}}$ & $\mathbf{t}_{\text {tabel }}$ \\
\hline $\mathrm{VIII}_{2}, \mathrm{VIII}_{3}$ & 0.184 & 1,243 & 1,68 \\
\hline
\end{tabular}

Berdasarkan pengujian korelasi product moment diperoleh tingkat hubungan Self Efficasy adalah 0.184 dengan tingkat hubungan sangat rendah. Selanjutnya untuk menguji kesignifikanan dari hubungan tersebut digunakan uji t. Hasil uji t pada taraf nyata $\propto=$ 0,05 dengan derajat kebebasan $(\mathrm{dk}=44)$ didapat harga $t_{\text {tabel }} 1,68$. Berdasarkan kriteria pengujian $t_{\text {tabel }}=1,68$ dan $t_{\text {hitung }}=1,243$. Maka $t_{\text {hitung }}<t_{\text {tabel }}$ yang artinya $\mathrm{H}_{\mathrm{i}}$ ditolak dan $\mathrm{H}_{0}$ diterima. Hasil dari pengujian hipotesis antara motivasi dengan hasil belajar fisika dapat dilihat pada Tabel 11 di bawah ini.

Tabel 11.Uji Hipotesis

\begin{tabular}{cccc}
\hline Kelas & $\mathbf{r}_{\mathbf{x y}}$ & $\mathbf{t}_{\mathbf{h}}$ & $\mathbf{t}_{\text {tabel }}$ \\
\hline $\mathrm{VIII}_{2}, \mathrm{VIII}_{3}$ & 0.089 & 0.593 & 1,68 \\
\hline
\end{tabular}

Berdasarkan pengujian korelasi product moment diperoleh tingkat hubungan motivasi adalah 0.089 dengan tingkat hubungan sangat rendah. Selanjutnya untuk menguji kesignifikanan dari hubungan tersebut digunakan uji t. Hasil uji t pada taraf nyata $\propto=$ 0,05 dengan derajat kebebasan $(\mathrm{dk}=44)$ didapat harga $t_{\text {tabel }} 1,68$. Berdasarkan kriteria pengujian yang didapat $t_{\text {tabel }}=1,68$ dan $t_{\text {hitung }}=0.593$. Maka $t_{\text {hitung }}<t_{\text {tabel }}$ yang artinya $\mathrm{H}_{\mathrm{i}}$ ditolak dan $\mathrm{H}_{0}$ diterima.

\section{Pembahasan}

Berdasarkan penelitian yang sudah dilakukan terhadap hubungan tingkat self efficacy, siswa yang tinggi memiliki nilai $\geq \mathbf{7 5}$ sebanyak 8 orang, tingkat self efficacy siswa yang sedang memiliki nilai $\geq \mathbf{7 5}$ sebanyak 6 orang siswa dan siswa yang tingkat self efficacy rendah memiliki nilai $\geq \mathbf{7 5}$ sebanyak 4 orang. Tingkat motivasi siswa tinggi memiliki nilai $\geq 75$ sebanyak 9 orang, tingkat motivasi siswa yang sedang memiliki nilai $\geq \mathbf{7 5}$ sebanyak 7 orang siswa dan siswa yang tingkat motivasi rendah memiliki nilai $\geq \mathbf{7 5}$ sebanyak 2 orang. Dari hasil penelitian didapatkan tidak semua siswa yang self efficacy tinggi memiliki hasil belajar yang tinggi, sebaliknya self efficacy siswa yang rendah ada juga hasil belajarnya tinggi, kalau hasil belajar tinggi berarti pemahaman konsep siswa juga tinggi. Self efficacy dan motivasi meupakan factor yang dapat meningkatkan pemahaman konsep siswa.karena self efficacy memiliki dimensi-dimensi keyakinan dalam taraf kesulitan tugas, keyakinan dalam ketahanan usaha serta keyakinan dalam kondisi apapun ( Banduru,1997). Berdasarkan dari hasil analisis self efficacy di dapatkan hubungan yang sangat rendah antara self efficacy dengan pemahaman konsep siswa, dari hasil uji hipotesis di dapatkan bahwa tidak terdapat hubungan yang signifikan antara self efficacy dengan pemahaman konsep siswa. Motivasi merupakan dorongan bagi seseorang untuk melakukan suatu tujuan, keinginan, dan harapan. Proses pembelajaran akan berhasil manakala siswa mempunyai motivasi dalam belajar. Berdasarkan hasil analisis terhadap motivasi dengan pemahaman konsep IPA didapatkan tidak semua siswa yang mempunyai motivasi tinggi pemahaman konsep nya tinggi,sebaliknya tidak semua yang memiliki motivasi rendah pemahaman konsepnya rendah. Hal ini di sebabkan siswa smp belum memahami maksud angket yang diberikan sehingga pengisian belum sesuai dengan keadaan sebenarnya siswa tersebut.

Prestasi belajar anak ditentukan oleh gabungan antara kecerdasan intelektual,self efficasy dan motivasi belajarnya. Meskipun anak-anak memiliki kecerdasan intelektual 
yang tinggi, jika tidak diikuti dengan self efficacy dan motivasi belajar yang tinggi maka prestasi belajarnya kurang memuaskan.Berdasarkan hasil penelitian menyatakan bahwa hubungan antara self efficacy dan motivasi menyatakan hubungan yang rendah terhadap hasil belajar hal ini disebabkan karena banyak factor yang mempengaruhi hasil belajar diantaranya Menurut Slameto (2010:54), faktor-faktor tersebut secara global dapat diuraikan dalam dua bagian, yaitu faktor internal dan faktor eksternal. Factor internal termasuk Intelegensi, perhatian, minat, bakat, motif, kematangan dan kesiapan.

\section{SIMPULAN}

Setelah dilakukan penelitian dengan judul Hubungan Self Efficasy dan Motivasi dengan Pemahaman Konsep IPA Terpadu Siswa Kelas VIII SMP pertiwi 2 PADANG. Berdasarkan analisis data Self Efficasy adalah 0.184 dengan tingkat hubungan sangat rendah. Berdasarkan pengujian kesignifikanan dari hubungan tersebut digunakan uji t, pada taraf nyata $\propto=0,05$ dengan derajat kebebasan $(\mathrm{dk}=44)$ didapat harga $\mathrm{t}_{\text {tabel }} 1,68$. Berdasarkan kriteria pengujian yang didapat $\mathrm{t}_{\text {tabel }}=1,68$ dan $t_{\text {hitung }}=1,243$. Maka $t_{\text {hitung }}<t_{\text {tabel }}$ yang artinya $\mathrm{H}_{\mathrm{i}}$ ditolak dan $\mathrm{H}_{0}$ diterima.

Tingkat hubungan motivasi adalah 0.089 dengan tingkat hubungan sangat rendah. Selanjutnya untuk menguji kesignifikanan dari hubungan tersebut digunakan uji t, pada taraf nyata $\propto=0,05$ dengan derajat kebebasan $(\mathrm{dk}=44)$ didapat harga $t_{\text {tabel }} 1,68$. Berdasarkan kriteria pengujian yang didapat $\mathrm{t}_{\text {tabel }}=1,68$ dan $\mathrm{t}_{\text {hitung }}=0.593$. Maka $t_{\text {hitung }}<t_{\text {tabel }}$ yang artinya $\mathrm{H}_{\mathrm{i}}$ ditolak dan $\mathrm{H}_{0}$ diterima.. Maka dapat disimpulkan bahwa tidak terdapat hubungan yang signifikan Self Efficasy dan Motivasi dengan Pemahaman Konsep IPA Terpadu Siswa Kelas VIII SMP Pertiwi 2 Padang.

\section{DAFTAR PUSTAKA}

Arikunto, Suharsimi. 2000. Manajemen Penelitian. Jakarta : Rineka Cipta.

Banduru,A (1997) self efficacy The excercise of control USA:WH Freemen dan company

Sugiono. 2010, Metode Penelitian Pendidikan Pendekatan Kuantitatif, Kualitatif, dan R \& D, Bandung, Alfabeta.

Sugiyono, 2014. Metode Penelitian Kuantitatif Kualitatif Dan R\&D. Bandung: Alfabeta.

Hamalik, Oemar. 2000. Psikologi Belajar dan Manager. Bandung : Sinar Baru Algessindo

Sardiman, A.M. 2001. Interaksi dan Motivasi Belajar Mengajar. Jakarta. PT. Raya Grafindo Persada.

A.M. Sardiman, 2005, Interaksi dan Motivasi Belajar Mengajar, Jakarta: PT RajaGrafindo Persada.

Purwanto. 2007. Psikologi Pendidikan. Bandung: Remaja Rosdakarya

Syaodih Nana Sukmadinata. 2005. Landasan Psikologi Proses Pendidikan. Bandung : PT Remaja Rosdakarya. 